\title{
e-Supply Chain Management for a Technology Company
}

\section{e-Supply Chain Management para una Empresa de Tecnología}

\author{
dx.doi.org/10.17981/ijmsor.01.01.04
}

Research Article - Reception Date: December 11, 2015 - Acceptance Date: December 30, 2015

\author{
Johana Nieves Cristancho \\ Universidad Piloto de Colombia \\ johananieves@hotmail.com, Bogotá, Colombia
}

Fernando Salazar Arrieta

Corporación Universidad de la Costa - CUC

fsalazar4@cuc.edu.co, Barranquilla, Colombia

To reference this paper:

J. Nieves Cristancho and F. Salazar Arrieta "e-Supply Chain Management for a Technology Company", IJMSOR, vol. 1, no. 1, pp. 31-34, 2016. DOI: dx.doi.org/10.17981/ijmsor.01.01.04

\begin{abstract}
The purpose of this paper is to analyze the paradigm shift developed with the technological revolution and the internet, and what drives business actors to rethink their strategies and be in constant technological upgrading that allows them to penetrate and evolve constantly in this new environment, and become more competitive, and on the other hand, to review the opportunity of integrating SCM environments to internet and cloud computing to achieve the definition of these new business strategies, based on more efficient and cost economic technology. It was particularly reviewed within a telecommunications and technology multinational that has resources, infrastructure of their own, and knowledge, and the opportunity to use those tools. An E-SCM was proposed for it, supported on exploration researches and E-SCM studies performed by several authors. The present paper briefly discusses the design of an E-SCM proposal in a telecommunications and technology company for its three main processes by using their existing resources.
\end{abstract}

Keywords-- Information and communication technologies (ICT), interactivity, value network, e-SCM, cloud computing.
Resumen-- El fin de éste artículo es analizar el cambio paradigmático que se gestó con la revolución tecnológica y con internet y que impulsa a los actores de negocios a que replanteen sus estrategias y estén en constante actualización tecnológica que les permita incursionar y evolucionar constantemente en este nuevo ambiente y ser así más competitivos y por otro lado revisar la oportunidad de integrar ambientes de SCM con internet y cloud computing para lograr definir esas nuevas estrategias empresariales basadas en tecnología más eficiente y de menor costo. Particularmente se revisó el caso dentro de una multinacional de telecomunicaciones y tecnología que cuenta con recursos, infraestructura propia y herramientas de conocimiento la oportunidad de aprovecharlos y se propuso un e-SCM para ésta, apoyado en la exploración de investigaciones y estudios acerca de e-SCM realizadas por varios autores. El presente artículo plantea brevemente el diseño de una propuesta de e-SCM en una empresa de telecomunicaciones y tecnología para sus tres procesos principales utilizando sus recursos actuales.

Palabras clave-- Tecnologías de información y comunicación (TIC), interactividad, red de valor, e-SCM, cloud computing. 


\section{INTRODUCTION}

The historical evolution and revolution of the information technologies presently allow an access to data and information, and a constant connectivity with people.

This has been concurrently happening in the corporate environment where businesses have been transformed by this revolution, which has set off a new information era, and new business models, based on profound technological and organizational transformation.

The corporate platforms focused on generation of value, in information and knowledge management, become critical components for national and international development [1]

E-SCM is then the result of using those information technologies and electronic media, with the purpose of gathering value networks in internet environments and with technological tools, allowing the interactivity, dynamism, integration and improvement in regard to knowledge exchange, coordination, upstream and downstream, information administration and control in a more effective way and in real time.

Some authors define e-SCM as the focused process in the Integration of network general activities of SCM, through tools gathered from the internet development context. But they give a more complete description of e-SCM, retaking the definition of those who state that e-SCM "refers to the impact that the Internet has in the integration of key business processes for the final user, through the original providers that offer products, services and information that add value for the clients and other interested parties" [2].

The crowded contemporary commercial stage where, thanks to the value networks that integrate it and substantially improve the work of organizations that coherently recognize, value and adjust their links, alliances and processes to improve the way their products and services reach the final customer, Supply Chain Management consolidates and allows the companies to effectively reach activities integration and alignment, link and link up their networks in the different processes and activities that produce value [3].

The intention of this research is to analyze some of those questions, along with the support of the research results, executed in a company of the ICT sector, and analyzing their resources and tools, besides the research exploration and diverse contributions about E-SCM performed by several authors.

That company that allowed to carry out the research, has tools and physical resources of state of the art technology, besides the human capital, enough to develop a program in cloud that allow their three main processes like sales, resale and operations to integrate under a E-SCM environment, that helps generate efficient answers for their internal and ex- ternal clients, greater productivity, synergy among their value networks and even use and know in the interior of the company the technological products that make part of the company portfolio in this era of cloud computing.

Precisely the general purpose intended by this article is to able to determine to what point this company that offers state of the art technology products and services to different corporations, knows and uses its own products, resources, tools, and developments, applying them to their inner value networks starting from their information and communication technologies (ICT).

\section{Methodological Aspect}

To understand the E-SCM concept and its applicability to the research target company, diverse bibliographical sources were consulted. On the other hand, the research is of exploratory character, since the use of ICT was directly enquired in the company, by applying surveys and interviews to different employees linked to the processes involved in the study. One of the most important aspects was the finding of low or almost nonexistent levels of use of ICT, and of their own resources and products.

For the development of field work, the information was collected in the company through observation and staring from a sampling by finite population, through the design and application of an instrument like a survey which had measuring variables like: knowledge and use of the company technological platform, knowledge and use of the company technological infrastructure, transference of information among processes, use of resources and company service portfolio products, quality and quantity of shared information among processes.

Sample definition was carried out through the following criteria selection: linking with the company and process to which the employee is linked.

Consequently, on chart 1 are shown the related variables to the selected sample size

Chart 1. Selected Sample Description

\begin{tabular}{|c|c|c|}
\hline Variable & Description & Selection Criteria \\
\hline $\begin{array}{c}\text { All the } \\
\text { population }\end{array}$ & 100 & $\begin{array}{c}\text { Universe of employees } \\
\text { of the Company under } \\
\text { study in Colombia }\end{array}$ \\
\hline $\begin{array}{c}\text { Sample } \\
\text { size }\end{array}$ & 60 & $\begin{array}{c}\text { Company personnel } \\
\text { linked to sales, Pre-sales } \\
\& \text { operation processes }\end{array}$ \\
\hline
\end{tabular}

Source: Author.

During the exploration exercise and field work a metric was used to define the usage level and knowledge of technological tools, approaching the use of ICT and its utilization degree, together with the other products and services 
Do you use the virtualization tools that your company has to share information in real time with its co-workers from other areas?

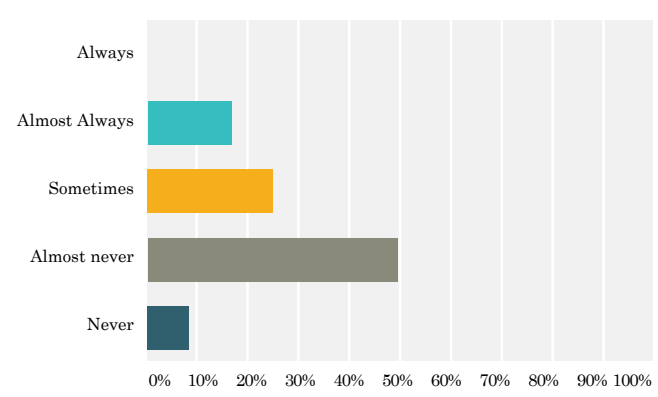

Fig. 1. Company ICT Knowledge and Use. Source: Author

Since sistematization and virtualization are key products of a company portfolio, do you consider that the company is:

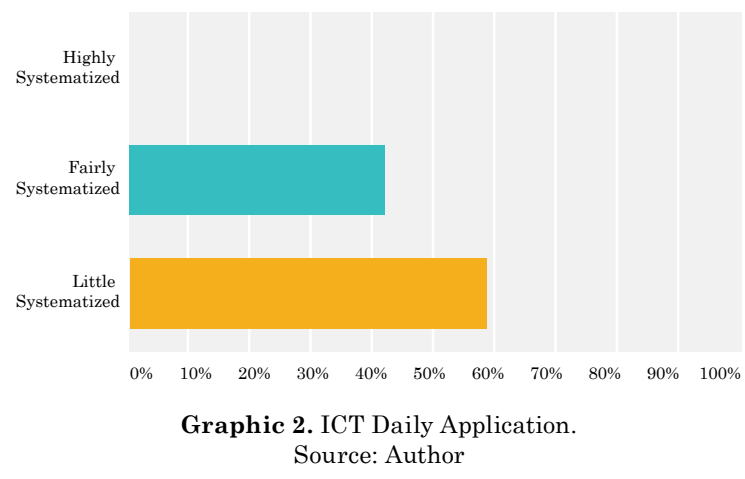

\section{III.RESUlts AND Discussion}

Chart 1 shows that $60 \%$ of the company population belongs to some of the three selected processes for the study, which are SALES, PRE SALES AND OPERATIONS. Processes that, because of their characteristics, should apply and use latest generation ICT which the company has, to improve communication and general processes. However, as we see on graphic 1, contrary to the above, the majority of involved personnel almost never use the available ICT.

In the same manner, graphic 2 shows the null perception by surveyed employees, of belonging to a highly systematized company, when it is one of the most important ICT developers in the global market

It is well known that the competitiveness paradigms have advanced towards the use of ICT to consolidate links among connected supply and support sectors [4].

On the present scientific article, it is observed that the global companies dedicated to develop ICT, should be their own labs, incorporating it in their business and practice with their employees, with each virtualization and systematization product, linking it to their work with their technological applications.
In our case, we observe that the three selected processes have not taken into account the importance of using these resources to facilitate their work, getting away from the opportunity of consolidating those links among their inner value networks, and they do not use them because they lack a tool to integrate the answer to their needs and use the network they have which is strong, and this would improve their competitive advantage. And they do not use them because they consider them inefficient, but because they lack the development to solve their internal communication and information problems.

ICT represent the key factor to strengthen businesses, one by one, from business to business, and of multiple and collaborative businesses, capable of increasing the strategy, the structure and processes in the dynamic competition of regions [5].

So, the integration of processes is the consequence of the ability of the businessmen to achieve synergies among suppliers, producer companies and consumers that economically influence sustainability inside each value network related to the productive system [6].

It can be stated that in regard to ICT usage, the Supply Chain Management (SCM) is recommended as a technological application strategy that makes possible for information technology to play an important role in traceability [7].

\section{A. A Dynamic Proposal of easy development for the study target company}

The company is a multinational with offices in more than 220 countries, a developer of telecommunication services and mass and corporative technologies. It has 5 main nodes in Colombia to provide telecommunication and technology services to local companies, and to other big multinationals of all sectors. It also has 60 electronic engineers, with training and constant certification in technologies and IT advances.

The company, within its products and services portfolio has storage centers development that include the service of cloud computing. The term cloud computing is not new or revolutionary but a term that has evolved with time. It started in the eighties under the concept of grid computing, although with certain differences and aimed to virtual servers; then in the nineties it expanded, raising the level of abstraction of virtual servers, first as virtual platform, and later as virtual applications; later on the term utility Computing was known, which offers clusters as virtual platforms; recently the term Software as Service (SaaS) raised the virtual level of applications with a business model not charged with consumed resources [8].

Due to this evolution, the concept of cloud computing combines the former terms of Grid, Utility and SaaS, and it is an emerging model where users may 
have access to applications from any place, through the connected devices [8].

A correct alignment between the corporate and local strategies would allow local collaborators to become more familiar with the use of virtual tools and cloud computing to improve their work, since the global products developed by the company are of latest generation, and are applicable to any geographical place where the company has offices, to make use of those resources and implement their E-SCM solution.

It is then viable to create in cloud (which the company under study has, and it is managed and supervised by the same), a virtual space where each local clients' profile is stored, together with their documents and all the corresponding information which must be defined for the collaborators of the three processes.

In this space, besides storing the information per client, there opens a communication gateway among the involved processes to keep opportune, updated and real time information there, of each news of the clients, in such a way that the value network members use the tool to develop their daily activities, in a simple manner, through alert messages sent to each email linked to the client's commercial account, where there can be forums and updates.

Within cloud, each activity must be recorded to have a registry of all events and situations associated to the client, in order for this proposed value network to synchronize and efficaciously share information that reflects their customer service, and that can be replicated later, including all other company value networks and suppliers.

\section{B. E-SCM Proposal Benefits}

The commissioning of this E-SCM proposal makes possible:

- Visibility to all collaborators and users of the virtual space about the client's news, from the moment a purchase order is uploaded until the service final delivery, and all its maintenance and associated news.

- Processes Elimination.

- It eliminates the information gaps among processes referring to specific clients.

- Allows more agility and certainty of correct and concrete information in real time.

- Allows the collaborators users of the virtual space to experience and apply in their work all the company products benefits offered within the portfolio of their cloud computing and B2B.

- Avoids excess costs due to wrong information.

- Facilitates communication among processes, which improves company ambience.

- Integrates company value networks by using their latest technology resources and internet in cloud computing, allowing E-SCM generation.
- Allows a clear visibility of the fulfillment of responsibilities and opportune management of each collaborator and process.

- Keeps updated the history of registered activities with the client.

- Reports paperwork application and processing time from and for the client.

- Facilitates safe access to information from any device and from any place with internet

\section{III.CONCLUSIONS}

Supply Chain Management (SCM) is the use of information technologies, electronic tools or cyberspace to integrate value networks

This study allowed to document all the integration process between SCM and all information technologies; exploring the concepts models and studies which let us understand the scope of the proposal and were the guide to dimension the efforts the company must make to transform its present business processes and adapt them to the digital era.

The topics approached allowed us to define the feasibility of the proposal since the nature of the company and the developments it has facilitate the insertion of the program; which should not be longer than month in becoming the definitive tool of regular use for the collaborators of the involved processes:

The digital era facilitates to technology companies to become protagonists and become labs for their own products; to perfect them and live the experience of the portfolio they sell from inside.

\section{References}

[1] D. H. Flórez M., A. Morales, C. P. Uribe G., and C. A. Contreras P., "Análisis de tendencias en investigación básica para cadenas productivas agroindustriales," Corpoica Cienc. y Tecnol. Agropecu., vol. 13, no. 2, pp. 121-135.

[2] C. Giménez Thomsen and H. Ramalhinho Dias Lourenço, "E-Supply Chain Management: Review, Implications and Directions for Future Research," SSRN Electron. J., Sep. 2004.pp.1-41. DOI: 10.2139/ssrn.848424

[3] J. Gattorna, Living Supply Chains: How to Mobilize the Enterprise Around Delivering what Your Customers Want. Financial Times Prentice Hall, 2006

[4] D. M. Lambert, "A global view of supply chain management”, Bussiness Review, vol 10, no. 2, 2008.

[5] P. Romano, U. of Udine, P. Danese, and U. of Padova, "Creating E-Clusters: A New Challenge for Supply Chain Management," Supply Chain Forum, vol. 10, no. 18, pp. 78-90, 2009

[6] A. F. Otchere, J. Annan, and E. K. Anin, "Achieving Competitive Advantage through Supply Chain Integration in the Cocoa Industry: A Case Study of Olam Ghana Limited and Produce Buying Company Limited," Int. J. Bus. Soc. Res., vol. 3, no. 2, pp. 131-145, 2013.

[7] P. Chrysochou, G. Chryssochoidis, and O. Kehagia, "Traceability information carriers. The technology backgrounds and consumers' perceptions of the technological solutions", Appetite, vol. 53, no. 3, pp. 322-31, Dec. 2009. DOI: $10.1016 /$ j.appet.2009.07.011

[8] Quan, D., \& Diep, C. C. (2008). From Cloud Computing to the New Enterprise Data Center. IBM Corporation. 